\title{
Spatial distribution and risk factors for Toxoplasma gondii seropositivity in cattle slaughtered for human consumption in Rondônia, North region, Brazil
}

\author{
Juliana Bianca Rocha de Souza ${ }^{a}$, Vando Edésio Soares ${ }^{a}$, Maerle Oliveira Maia ${ }^{a}$, \\ Cleidiane Magalhães Pereira ${ }^{\mathrm{a}}$, Antônio Sergio Ferraudo ${ }^{\mathrm{b}}$, Breno Cayeiro Cruz ${ }^{\mathrm{c}}$, \\ Weslen Fabrício Pires Teixeira ${ }^{c}$, Gustavo Felippelli ${ }^{c}$, Willian Giquelin Maciel ${ }^{c}$, \\ Walter Antonio Gonçalves Junior ${ }^{\mathrm{d}}$, Alvimar José da Costa ${ }^{\mathrm{c}}$, \\ Welber Daniel Zanetti Lopes ${ }^{\mathrm{e}, *}$

\footnotetext{
a UNICASTELO - Universidade Camilo Castelo Branco, Av. Hilário da Silva Passo 950, Descalvado, São Paulo, 13690-970, Brazil

b Departamento de Matemática, Universidade Estadual Paulista (Unesp), Campus de Jaboticabal, Via de acesso Prof. Paulo Donato Castellane s/n, Jaboticabal, SP, 14884-900, Brazil

${ }^{\mathrm{C}}$ CPPAR - Animal Health Research Center - Faculdade de Ciências Agrárias e Veterinárias, UNESP, Via de acesso prof. Paulo Donatto Castellani, s/n, 14884-900, Jaboticabal, São Paulo, Brazil

' Universidade Estadual de Maringá (UEM), Campus Regional de Umuarama, PR, Brazil

e Instituto de Patologia Tropical e Saúde Pública, Universidade Federal de Goiás (IPTSP/UFG), Goiânia, Goiás, 74605050, Brazil
}

\section{A R T I C L E I N F O}

\section{Article history:}

Received 22 December 2015

Received in revised form 3 July 2016

Accepted 9 July 2016

\section{Keywords:}

Indirect immunofluorescence assay (IFAT)

Serology

Toxoplasma gondii

Rondônia

Brazil

\begin{abstract}
A B S T R A C T
The present study aimed to evaluate Toxoplasma gondii seroprevalence in cattle slaughtered for human consumption from rural properties in the state of Rondônia, North region, Brazil; the seroprevalence was determined using indirect immunofluorescence assays (IFATs). Additionally, spatial distribution and risk factors associated with toxoplasmosis were also analyzed. Of the 1000 cattle serum samples examined, 53 (5.3\%) were determined to be seropositive for $T$. gondii with antibody titers $(\operatorname{IgG}) \geq 64$. In regard to results of the studied risk factors (presence of cats, cats with free access to cattle, breeding system, animal's gender, consumption of raw milk by humans on the property and cattle abortion in the last 12 months) and the odds ratio (OR) of each of these factors influencing cattle to acquire toxoplasmosis, only animals raised on a feeder/stocker/backgrounder system presented a higher probability of being seropositive for $T$. gondii $(\mathrm{OR} \geq 1, \mathrm{P}=0.04)$ than cattle raised only in a feeder/stocker system. There was no association between the occurrence of reproductive problems and T. gondii seropositivity. Based on results obtained in the Brazilian state of Rondônia, it could be concluded that the presence of cats and their contact with cattle on each property, cattle breeding purpose and cattle abortion in the last 12 months were not considered risk factors for $T$. gondii infection in cattle. Considering that the presence of $T$. gondii was detected in animals slaughtered in the state of Rondônia, consuming raw or undercooked meat from seropositive cattle should be considered a route of transmission of $T$. gondii to humans. However, the prevalence of toxoplasmosis diagnosed in cattle from this state $(5.30 \%)$ is lower than the prevalence of toxoplasmosis observed in South, Southeast and Center-West regions of Brazil, which may vary between $48.5 \%$ and $71.0 \%$. The low prevalence of toxoplasmosis in cattle is highlighted in Rondônia, which is the sixth largest state for cattle slaughtering in Brazil and is responsible for producing $20 \%$ of all cattle meat exported by Brazil.
\end{abstract}

(C) 2016 Elsevier B.V. All rights reserved.

\footnotetext{
* Corresponding author.

E-mail addresses: wdzlopes@hotmail.com, l.warris@erasmusmc.nl (W.D. Zanetti Lopes).
}

\section{Introduction}

Toxoplasma gondii is a protozoan with a heteroxenous life cycle that is able to infect all homoeothermic animal species, including mammals, birds and humans (Dubey, 1996; Lopes et al., 2013). Tox- 
oplasmosis was first diagnosed in cattle by Houersdorf and Holtz (1952) in Germany, as cited by Mayer (1965).

In cattle destined for human consumption in Brazil, 19.2\% to 71\% (Suarez-Aranda et al., 2000; Santos et al., 2009) tested seropositive for $T$. gondii. These percentages reinforce the importance of meat consumption derived from these animals, as well as their byproducts, as a possible route of transmission of $T$. gondii to humans (Dubey, 1996). Evidence can be obtained from outbreaks of human toxoplasmosis through ingestion of viable cysts or tachyzoites of T. gondii present in salami (Dias et al., 2005) and steak tartare (Eduardo et al., 2007).

Based on previously described information, no studies are available in the known literature regarding the prevalence of toxoplasmosis in cattle from the state of Rondônia, North region, Brazil. Because cattle toxoplasmosis represents a major importance for public health in general, the present study aimed to determine the seroprevalence of $T$. gondii in cattle from the state of Rondônia, which were slaughtered for human consumption, using indirect immunofluorescence assays (IFATs). The present study also analyzed the seropositive spatial distribution and risk factors associated with $T$. gondii infection in cattle.

\section{Materials and methods}

The state of Rondônia is located in the North region of Brazil. Serum samples were collected between March and May 2015 from cattle from a slaughterhouse located in the city of Rolim de Moura, on the eastern side of Rondônia. In total, 1000 animals were sampled, originating from 39 rural properties that belonged to 21 municipalities in Rondônia. From each property, samples were collected from all cattle sent to the aforementioned slaughterhouse.

Ten $\mathrm{mL}$ blood samples were collected from each animal during the slaughter procedures through venipuncture, and blood was in sterile tubes. In the laboratory, these samples were centrifuged at $1000 \times g$ for $10 \mathrm{~min}$. Then, the sera were stored in polypropylene tubes at $-20^{\circ} \mathrm{C}$.

Serum samples were analyzed using IFAT for the detection of IgG class anti-T. gondii antibodies, following the technique described by Camargo (1964) and using the cattle anti-IgG conjugate (SigmaChemical F7887-1 mL) produced in rabbits. All reactions included previously known standard serum samples, both positive and negative. The reading was conducted under a fluorescent microscope and positivity of samples was confirmed when titers $\geq 64$ were obtained. Aiming to verify anti-T. gondii antibody titers present in samples diagnosed as positive, these same samples were later diluted $(1: 128,1: 356,1: 512,1: 1024$ and 1:4096) in PBS solution for the research of antibodies against the protozoan being studied.

To estimate possible risk factors for $T$. gondii in herds originating from Rondônia, North region, Brazil, the 39 properties were visited and a questionnaire was designed to ask the owner of these animals the following questions: 1 ) What is the main herd activity (beef or milk)? 2) What is the breeding system (feeder, stocker, backgrounder)? 3) Are there any cats on the property? 4) If yes, do the cats have access to cattle? 5) Are animals slaughtered on the property? 6) Were there any spontaneous abortion cases in the last 12 months? 7) Do people on the property consume raw milk? Data regarding age, gender and origin of such animals were collected directly from the slaughterhouse.

The independent effects between the selected variables and the seropositivity, risk factors and odds ratio (OR) were estimated, with a confidence interval equal to $95 \%$ (IC 95\%) between subgroups formed from each variable. Difference in seroprevalence between genders was verified using the Fisher Exact Test and Pearson's chisquare test. All analyses were obtained using Statistica software, version 10 (StatSoft Inc., 2011).

\section{Results}

From all 1000 cattle serum samples examined, 53 (5.3\%) were diagnosed as positive for $T$. gondii with antibody titers $\geq 64$ (Table 1 ).

Analyzing results from the studied period, it can be observed that from all 21 municipalities where serum samples were obtained, seven (Ariquemes, Campo Novo de Rondônia, Nova Colina/Jí-Paraná, Nova União, Rolim de Moura, Theobroma and Vale do Paraíso) presented no cattle diagnosed as seropositive for T. gondii. In the remaining 14 locations that presented animals with anti-T. gondii antibodies (Fig. 1), the observed seroprevalence ranged between 2.0\% (Cacoal) and 16.7\% (Ouro Preto do Oeste).

According to results described on Table 1, Colorado do Oeste, Nova Brasilândia do Oeste, Outro Preto do Oeste and Presidente Médici were the municipalities which presented the highest probability of finding cattle positive for toxoplasmosis (Odds ratio $[\mathrm{OR}] \geq 1$ ).

Regarding the evaluated risk factors and the odds ratio (OR) of each of the factors influencing cattle in acquiring toxoplasmosis (presence of cats, cats have access to cattle, creation system, livestock activity, sex, raw milk consumption, slaughter of animals on the property and abortion in the last 12 month), only animals raised in a feeder/stocker/backgrounder system presented a higher probability of being seropositive for $T$. gondii ( $O R \geq 1, P=0.048$ ), when compared to animals raised in a feeder/stocker system only. There was no association between occurrence of reproductive problems in cattle and serological reactions to $T$. gondii.

\section{Discussion}

According to Hall et al. (2001), the presence of antibodies against T. gondii varies between 0 and $99 \%$, which is described in the worldwide literature. The mean serological prevalence of $T$. gondii observed in cattle from the present study was $5.3 \%$, a value that can be considered low in comparison to results obtained in cattle from the following states: Paraná, South region, Brazil; São Paulo and Minas Gerais, both in the Southeast region, Brazil; and Mato Grosso, in the Center-West region of the country (Marana et al., 1995; Costa et al., 2001; Ogawa et al., 2005; Santos et al., 2009); the cattle from these states were between $48.5 \%$ and $71.0 \%$ seropositive for T. gondii. The lower seroprevalence value observed in cattle from the state of Rondônia is probably explained, in part, by the low cattle population density observed in this state (6.58 pop. per $\mathrm{km}^{2}$ ) compared to the cattle population density of the other states, such as São Paulo (166.23 pop. per km²), Minas Gerais (33.41 pop. per $\mathrm{km}^{2}$ ), and Paraná (52.40 pop. per $\mathrm{km}^{2}$ ) (IBGE, 2015). There are studies demonstrating a positive correlation between density of the human population and number of domestics cats (Denny and Dickman, 2010; Lessa and Bergallo, 2012). In others words, if the population of humans is high, the domestic cat population is also high. This means the high population density of humans correlates with a more common presence of infected domestic cats, which consequently, increases the environmental contamination of Toxoplasma gondii oocysts in these areas and could infect the cattle by the consumption of contaminated water or food. The population density of Mato Grosso (3.36 pop. per $\mathrm{km}^{2}$ ) is less than that of Rondônia, but Santos et al. (2009), diagnosed $71 \%$ of cattle as seropositive for $T$. gondii in milk herds. Is important to mention that the study conducted in Mato Grosso by these authors was performed in three neighboring municipalities (Araputanga, Jarú and São José dos Quatro Marcos) in this state, and likely, there are some epidemiological aspects in this specific region that should be considered for justifying the high prevalence of $T$. gondii in cattle found by Santos et al. (2009). 
Table 1

Analysis between the prevalence of Toxoplasma gondii (IFAT), in cattle to different municipalities in the state of Rondonia, Brazil.

\begin{tabular}{|c|c|c|c|c|c|c|c|c|c|c|c|c|c|c|}
\hline \multirow[t]{2}{*}{ City of State of Rondônia } & \multirow{2}{*}{$\begin{array}{l}\text { Number of } \\
\text { properties }\end{array}$} & \multirow{2}{*}{$\begin{array}{l}\text { Total of } \\
\text { samples }\end{array}$} & \multirow{2}{*}{$\begin{array}{l}\text { Representation } \\
\text { of the region } \\
\text { with respect to } \\
\text { the total sampled } \\
\text { cattle }\end{array}$} & \multirow{2}{*}{$\begin{array}{l}\text { IFAT positive for } \\
\text { T. gondii }\end{array}$} & \multirow[t]{2}{*}{ Prevalence } & \multicolumn{3}{|c|}{ Odds ratio $(\mathrm{OR})^{\mathrm{a}}$} & \multicolumn{6}{|c|}{ Title for $T$. gondii/Number of cattle } \\
\hline & & & & & & Value & $\begin{array}{l}\text { Significance } \\
\text { level }\end{array}$ & 95\% CI: & $>64$ & $>128$ & $>356$ & $>512$ & >1024 & $>4096$ \\
\hline Ariquemes & 1 & 36 & $3,6 \%$ & 0 & $0,0 \%$ & 0,0 & - & - & - & - & - & - & - & - \\
\hline Buritis & 2 & 15 & $1,5 \%$ & 2 & $13,3 \%$ & 2,7 & 0,19 & $0,604-12,496$ & 2 & - & - & - & - & - \\
\hline Cacaulândia & 2 & 51 & $5,1 \%$ & 2 & $3,9 \%$ & 0,7 & 0,667 & $0,172-3080$ & 1 & - & - & 1 & - & - \\
\hline Cacoal & 3 & 102 & $10,2 \%$ & 2 & $2,0 \%$ & 0,3 & 0,157 & $0,085-1488$ & 2 & - & - & - & - & - \\
\hline Campo Novo de Rondônia & 2 & 8 & $0,8 \%$ & 0 & $0,0 \%$ & 0,0 & - & - & - & - & - & - & - & - \\
\hline Castanheiras & 1 & 21 & $2,1 \%$ & 2 & $9,5 \%$ & 1,8 & 0,403 & $0,426-8287$ & 2 & - & - & - & - & - \\
\hline Colorado do oeste & 1 & 71 & $7,1 \%$ & 8 & $11,3 \%$ & 2,2 & 0,041 & $1033-4979$ & 7 & - & 1 & - & - & - \\
\hline Jaru & 1 & 19 & $1,9 \%$ & 1 & $5,3 \%$ & 0,9 & 0,994 & $0,130-7578$ & - & 1 & - & - & - & - \\
\hline Ji-Paraná & 1 & 33 & $3,3 \%$ & 2 & $6,1 \%$ & 1,1 & 0,848 & $0,268-4946$ & - & 2 & - & - & - & - \\
\hline Machadinho do Oeste & 4 & 207 & $20,7 \%$ & 8 & $3,9 \%$ & 0,7 & 0,393 & $0,336-1534$ & 3 & 3 & 2 & - & - & - \\
\hline Ministro Andreazza & 1 & 15 & $1,5 \%$ & 1 & $6,7 \%$ & 1,2 & 0,815 & $0,164-9889$ & 1 & - & - & - & - & - \\
\hline Nova Brasilândia do Oeste & 1 & 37 & $3,7 \%$ & 6 & $16,2 \%$ & 3,4 & 0,008 & $1382-8651$ & 2 & 1 & 3 & - & - & - \\
\hline Nova Colina/Ji-Paraná & 1 & 56 & $5,6 \%$ & 0 & $0,0 \%$ & 0,0 & - & - & - & - & - & - & - & - \\
\hline Nova Estrela de Rondônia/Rolim de Moura & 5 & 27 & $2,7 \%$ & 1 & $3,7 \%$ & 0,6 & 0,715 & $0,091-5162$ & 1 & - & - & - & - & - \\
\hline Nova União & 2 & 17 & $1,7 \%$ & 0 & $0,0 \%$ & 0,0 & - & - & - & - & - & - & - & - \\
\hline Ouro Preto do Oeste & 1 & 36 & $3,6 \%$ & 6 & $16,7 \%$ & 3,5 & 0,007 & $1425-8959$ & 4 & 1 & - & - & 1 & - \\
\hline Presidente Médici & 3 & 55 & $5,5 \%$ & 9 & $16,4 \%$ & 3,4 & 0,001 & $1,625-7,520$ & 5 & 3 & 1 & - & - & - \\
\hline Rolim de Moura & 1 & 8 & $0,8 \%$ & 0 & $0,0 \%$ & 0,0 & - & - & - & - & - & - & - & - \\
\hline São Francisco do Guapoé & 2 & 113 & $11,3 \%$ & 3 & $2,7 \%$ & 0,4 & 0,232 & $0,149-1585$ & 3 & - & - & - & - & - \\
\hline Theobroma & 2 & 64 & $6,4 \%$ & 0 & $0,0 \%$ & 0,0 & - & - & - & - & - & - & - & - \\
\hline Vale do Paraíso & 2 & 9 & $0,9 \%$ & 0 & $0,0 \%$ & 0,0 & - & - & - & - & - & - & - & - \\
\hline Média ou Total & 39 & 1000 & $100,0 \%$ & 53 & $5,3 \%$ & & - & - & 33 & 11 & 7 & 1 & 1 & 0 \\
\hline
\end{tabular}

a Cattle of municipalities with odds ratio $(\mathrm{OR}) \geq 1$ are more likely to contain toxoplasmosis. 


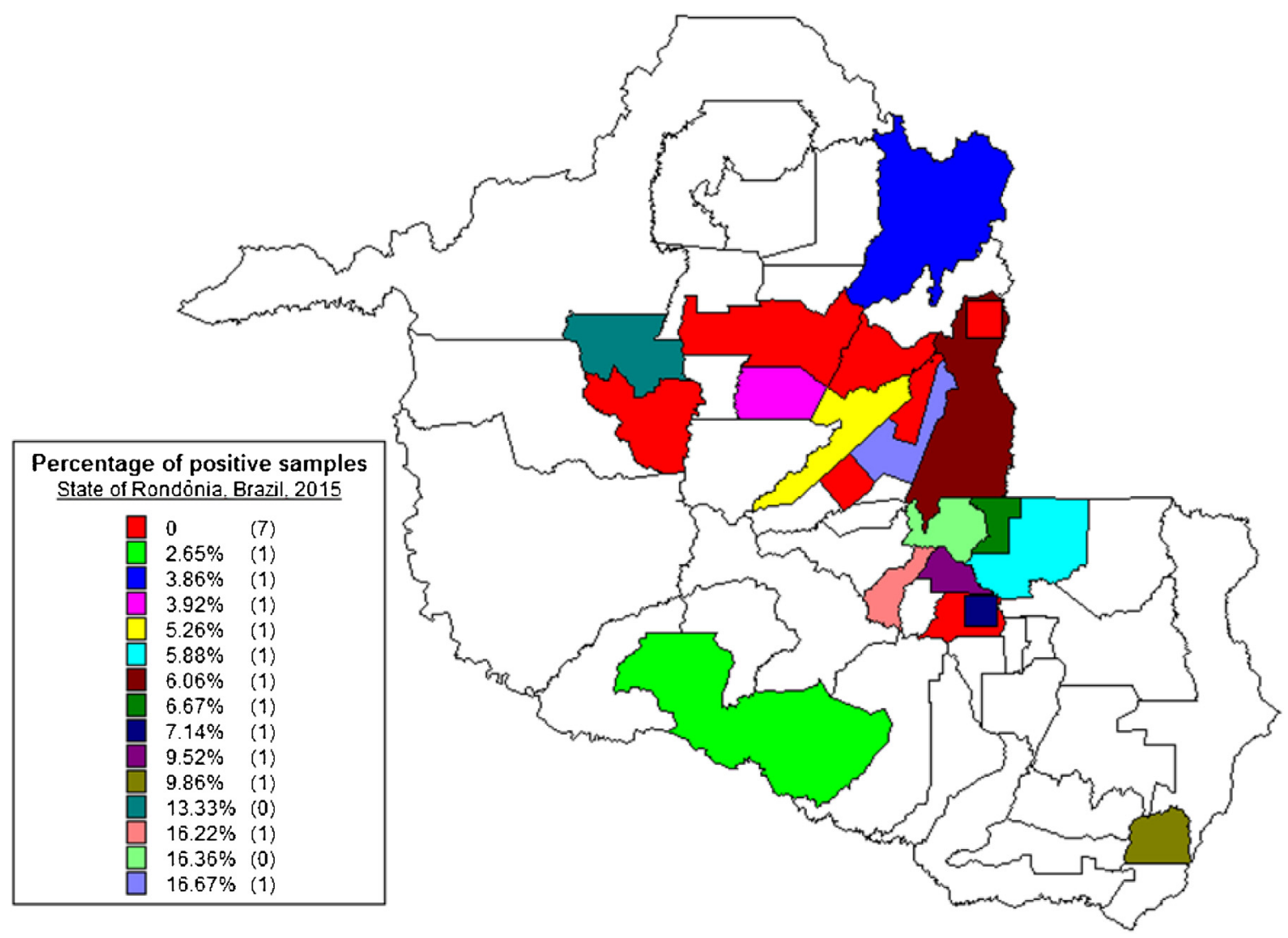

Fig. 1. Percentage of samples positive for Toxoplasma gondii in each participant city of State of Rondônia, Brazil.

In the present study, all beef cattle farms contained breeding, rearing and fattening cattle rearing system. The same breeding system was used for beef dairy cattle. These animals were not acquired (purchased) from other properties. They were raised on extensive grazing, supplemented with grains or hay, and kept on pasture of Brachiaria brizantha cv. BRS Pietã. In all 39 herds analyzed, located in 21 municipalities, the presence of anti-T. gondii antibodies was not diagnosed in 20 properties (51.3\%). On the remaining 19 evaluated properties, seropositivity for the aforementioned protozoan varied between $1.96 \%$ and $16.67 \%$. Amongst positive samples, the highest serological titer observed was 1024 , presented in only one animal. The most frequent titers were 64 (62.26\%) and $128(20.75 \%)$. According to Dubey and Thulliez (1993), cattle possessing anti-T. gondii titers $\leq 1024$ have chronic toxoplasmosis infections with the presence of tissue cysts that can remain alive up to 1191 days in these animals' organs. Such an observation, previously described by aforementioned researchers, allow us to infer that cattle analyzed in Rondônia were presenting chronic cases of toxoplasmosis because $100 \%$ of all cattle were diagnosed with antibody titers against $T$. gondii $<1024$.

The presence and contact of cats with cattle were not risk factors $(\mathrm{P}>0.05)$ for cattle to acquire toxoplasmosis in the present study. Similar results were obtained by Garcia et al. (1999) in the state of Paraná, South region, Brazil, and by Santos et al. (2009) in Mato Grosso, a state located in Center-West region, Brazil. In the present study, although of presence of cats was not a risk factor for cattle to acquire toxoplasmosis, the farms that had no cats had no seropositive cattle for $T$. gondii. Interestingly, during the visits, all owners reported the sporadic presence of wild felines, and in some cases we saw footprints of these animals on the farms. Future epidemiological studies must be conducted on wild felines of this particular region.
Based on results found on the state of Rondônia, located on the far North region of Brazil, it was possible to conclude that the presence of cats, their contact with cattle, livestock activity and cases of abortion on the last 12 months were not risk factors for toxoplasmosis in cattle. Considering that $T$. gondii seropositivity was diagnosed in cattle slaughtered in the state of Rondônia, raw or undercooked meat from these animals must be considered as a source of transmission for humans who ingest such products. However, the average seroprevalence of $T$. gondii detected in cattle in Rondônia (5.30\%), is lower compared to mean T. gondii seroprevalence observed in cattle South, Southeast and Center-West regions of Brazil, which varied between $48.5 \%$ and $71.0 \%$. This fact highlights seroprevalence of $T$. gondii in Rondônia, which is the sixth largest cattle slaughterer in Brazil and is responsible for producing $20 \%$ of all cattle meat exported by Brazil.

\section{References}

Camargo, M.E., 1964. Improvised technique of indirect immunofluorescence for serological diagnosis of toxoplasmosis. Rev. Inst. Med. Trop. 06, 117-118.

Costa, G.H.N., Cabral, D.D., Varandas, N.P., Sobral, E.A., Borges, F.A., Castagnolli, K.C., 2001. Freqüência de anticorpos anti-Neospora caninum e anti-Toxoplasma gondii em soros de bovinos pertencentes aos estados de São Paulo e de Minas Gerais. Semina 22, 61-66.

Denny, E.A., Dickman, C.R., 2010. Review of Cat Ecology and Management Strategies in Australia. Invasive Animals Cooperative Research Centre Canberra Press, 84 pp.

Dias, R.A.F., Navarro, I.T., Ruffolo, B.B., Bugni, F.M., Castro, M.V., Freire, R.L., 2005 Toxoplasma gondii em lingüiça de carne suína tipo frescal, com investigação soroepidemiológica em trabalhadores de estabelecimentos produtores. Rev. Inst. Med. Trop. 47, 185-189.

Dubey, J.P., Thulliez, P.H., 1993. Persistence of tissue cysts in edible tissues of cattle fed Toxoplasma gondii oocysts. Am. J. Vet. Res. 54, 270-273.

Dubey, J.P., 1996. Strategies to reduce transmission of Toxoplasma gondii to animals an humans. Vet. Parasitol. 64, 65-70.

Eduardo, M.B.P., Katsuya, E.M., Ramos, S.R.T.S., Pavanello, E.I., Paiva, O.R., Brito, S.N., Madalosso, G., 2007. Investigação do surto de toxoplasmose associado ao 
consumo de prato à base de carne crua (steak tartar), nos municípios de São Paulo e Guarujá, SP Novembro de 2006. Bol. Epidemiol. Paul. 4, 1-4.

Garcia, J.L., Navarro, I.T., Ogawa, L., Oliveira, R.C., 1999. Soroprevalência do Toxoplasma gondii em suínos, bovinos, ovinos e eqüinos, e sua correlação com humanos, felinos e caninos, oriundos de propriedades rurais do norte do Paraná, Brasil. Ciênc. Rur. 29, 91-97.

Hall, S., Ryan, M., Buxton, D., 2001. The epidemiology of toxoplasma infection. In: Joynson, H.M., Wreghitt, T.G. (Eds.), Toxoplasmosis. A Comprehensive Clinical Guide. University Press, Cambridge, pp. 58-124.

IBGE, 2015. Brazilian Institute of Geographic and Statistics Municipalities, Avaiable in: http://cidades.ibge.gov.br/ (acessed on 12.5.15.).

Lessa, I.C.M., Bergallo, H.G., 2012. Modelling the population control of the domestic cat: an example from an island in Brazil. Braz. J. Biol. 72, 445-452.

Lopes, W.D.Z., Rodriguez, J.D., Souza, F.A., Santos, T.R., Santos, R.S., Rosanese, W.M. Lopes, W.R.Z., Sakamoto, C.A.M., Costa, A.J., 2013. Sexual transmission of Toxoplasma gondii in sheep. Vet. Parasitol. 195, 47-56.

Marana, E.R.M., Venturi, A.C.H., Freire, R.Ç., 1995. Ocorrência de anticorpos anti-Toxopalsma gondii em rebanhos de bovinos do norte do Paraná, Brasil. Semina 16, 40-42.
Mayer, H.F., 1965. Investigaciones sobre toxoplasmosis. Bol. Of. Sant. Panm. 58, 485-497.

Ogawa, L., Freire, R.L., Vidotto, O., Gondim, L.F.P., Navarro, I.T., 2005. Ocorrence of antibodies to Neospora caninum and Toxoplasma gondii in dairy cattle from the northern region of the Paraná State, Brasil. Arq. Bras. Med. Vet. Zootec. 57, 27-32.

Santos, T.R., Costa, A.J., Toniollo, G.H., Luvizotto, M.C., Benetti, A.H., Santos, R.R. Matta, D.H., Lopes, W.D., Oliveira, J.A., Oliveira, G.P., 2009. Prevalence of anti-Toxoplasma gondii antibodies in dairy cattle, dogs, and humans from the Jauru micro-region Mato Grosso state, Brazil. Vet. Parasitol. 161, 324-326.

StatSoft Inc, 2011. STATISTICA (Data Analysis Software System) Version 10 , Available from: www.statsoft.com (cited 26.4.12.).

Suarez-Aranda, F., Galisteu, A.J., Hiramoto, R.M., Cardoso, R.P.A., Meireles, L.R., Miguel, O., Andrade, J.H.R., 2000. The prevalence and avidity of Toxoplasma gondii IgG antibodies in pigs from Brasil and Peru. Vet. Parasitol. 91, 23-32. 